J. Amer. Soc. Hort. Sci. 116(3):585-589. 1991.

\title{
Increased $\mathrm{CO}_{2}$ and Light Promote in Vitro Shoot Growth and Development of Theobroma cacao
}

\author{
Antonio Figueira, Anna Whipkey, and Jules Janick \\ Department of Horticulture, Purdue University, West Lafayette, IN 47907 \\ Additional index words. micropropagation, cacao
}

\begin{abstract}
Axillary shoots of cacao (Theobroma cacao L.), induced in vitro with cytokinins (BA or TDZ), elongated and produced leaves only in the presence of cotyledons and/or roots. Detached axillary shoots, which do not grow in 'vitro under conventional tissue culture protocols, rooted with auxin and developed normally in vivo. Detached axillary shoots from cotyledonary nodes and single-node cuttings from mature plants were induced to elongate and produce normal leaves in the presence of $20,000 \mathrm{ppm} \mathrm{CO}$ and a photosynthetic photon flux density (PPFD) of 150 to 200 $\mu \mathrm{mol} \cdot \mathrm{s}^{-1} \cdot \mathrm{m}^{-2}$. Subculture nodal cuttings continued to elongate and produce leaves under elevated $\mathrm{CO}_{2}$ and light levels, and some formed roots. Subculture of microcuttings under $\mathrm{CO}_{2}$ enrichment could be the basis for a rapid system of micropropagation for cacao. Chemical names used: $N$-(phenylmethyl) $-1 H$-purin-6-amine (BA); $1 H$-indole3-butyric 'acid (IBA); $\alpha$-naphthaleneacetic acid (NAA); thidiazuron (TDZ).
\end{abstract}

Cacao has been recalcitrant in tissue culture. Attempts to micropropagate cacao via shoot tip culture have been disappointing. Promotive factors reported include: 1) liquid medium (Adu-Ampomah et al., 1988; Blake and Maxwell, 1984; Dufour and Dublin, 1985; Orchard et al., 1979); 2) physiological stage of the explant source, i.e., either explanted during active flush (Passey and Jones, 1983) or during vegetative rest (Bertrand, 1987; Blake and Maxwell, 1984; Orchard et al., 1979); 3) frequent medium transfer (Adu-Ampomah et al., 1988; Blake and Maxwell, 1984; Legrand and Mississo, 1986); 4) decreased salt concentration (Bertrand, 1987; Dufour and Dublin, 1985); 5) increased culture vessel volume (Dufour and Dublin, 1985); 6) use of activated charcoal (Dufour and Dublin, 1985); 7) use of glucose as a carbon source (Legrand et al., 1984); and 8) explant length of 2 to $4 \mathrm{~cm}$ with medial bud placement (Legrand and Mississo, 1986; Litz, 1986). Despite these protocol improvements, only sporadic growth and proliferation of explanted shoots have been achieved. In many cases, shoot growth ceased after 4 to 6 weeks of culture (Adu-Ampomah et al., 1988; Blake and Maxwell, 1984; Legrand and Mississo, 1986; Legrand et al., 1984; Passey and Jones, .1983). No positive results were reported on subculture.

Recently, Flynn et al. (1990) reported bud elongation and leaf development from mature shoots cultured in vitro without exogenous growth regulators, but no data are presented comparing treatments. They reported promotive factors to include flush stage at explant excision, minimization of explant stress through careful handling, orientation of nodal explant within culture vessel, $10 \mathrm{~h}$ of light with a maximum of $250 \mu \mathrm{mol} \cdot \mathrm{s}^{-1} \cdot \mathrm{m}^{-2}$ programmed to reflect diurnal flux changes, high culture vessel relative humidity, and frequent explant transfer.

Previous studies in our laboratory (Janick and Whipkey, 1985) have indicated that shoots can be induced in vitro from cotyledonary nodal tissues of cacao after epicotyl decapitation or supplementation of the basal medium with BA. Shoots elongated and developed leaves in the presence of cotyledons, but proliferated. axillary shoots, when excised from the cotyledonary node, failed to grow under standard tissue culture protocols. The objective of this study was to investigate the growth of

Received for publication 29 Aug. 1990. Journal Paper no. 12635 of the Purdue Univ. Agricultural Experiment Station. We acknowledge the assistance of Sergio Filloy. The cost of publishing this paper was defrayed in part by the payment of page charges. Under postal regulations, this paper therefore must be hereby marked advertisement solely to indicate this fact. cacao shoots in vitro, emphasizing cotyledonary axillary shoots as a model system. Emphasis on $\mathrm{CO}_{2}$ and light was based on reports by Infante et al. (1989), Kozai (1990), and Lakso et al. (1986).

\section{Materials and Methods}

In vivo production and rooting of cotyledonary axillary shoots. Axillary cotyledonary nodel shoots were induced by removing the epicotyl from 1-month-old cacao seedlings grown in the greenhouse. Excised axillary shoots and epicotyls $(8 \mathrm{~cm}$ long) were dipped for $10 \mathrm{sec}$ in various concentrations of IBA and/or NAA in $50 \%$ ethanol as described (Tables 1 and 2). Shoots were transferred to a 1 soil : 1 perlite mixture (v/v) and misted

Table 1. Rooting of main and axillary shoots of 1-month-old seedlings of cacao in vivo, 3 weeks after treatment with $4000 \mathrm{ppm}$ IBA plus 4000 ppm NAA in $50 \%$ ethanol. ${ }^{2}$

\begin{tabular}{lccc}
\hline \hline $\begin{array}{l}\text { Shoot } \\
\text { type }\end{array}$ & $\begin{array}{c}\text { Rooting } \\
(\%)\end{array}$ & $\begin{array}{c}\text { Roots/ } \\
\text { cutting }\end{array}$ & $\begin{array}{c}\text { Root } \\
\text { length (mm) }\end{array}$ \\
\hline Main & 50 & $6.8 \pm 1.2^{y}$ & $21.0 \pm 1.8$ \\
Axillary & 80 & $6.7 \pm 0.9$ & $17.4 \pm 1.6$ \\
\hline
\end{tabular}

'Treatment $\mathrm{n}=30$.

${ }^{y} \pm$ SE.

Table 2. Effects of auxin on in vivo rooting of axillary shoots of seedling cacao. ${ }^{2}$

\begin{tabular}{lccc}
\hline \hline $\begin{array}{l}\text { Auxin } \\
\text { concn } \\
\text { (ppm) }\end{array}$ & \multicolumn{3}{c}{ Rooting (\%) } \\
\cline { 2 - 4 } & IBA & NAA & IBA + NAA \\
\hline 0 & $11.1^{\mathrm{w}}$ & $\ldots-$ & -- \\
40 & 37.5 & 20.0 & 33.3 \\
400 & 33.3 & 33.3 & 37.5 \\
2000 & 62.5 & 77.8 & 77.8 \\
4000 & 83.3 & 70.0 & 62.5 \\
8000 & 100.0 & 50.0 & -- \\
Significance & & & \\
$\quad$ Linear & $* *$ & $*$ & NS \\
Quadratic & $* *$ & $* *$ & $* *$ \\
\hline
\end{tabular}

${ }^{2}$ Data obtained after 3 weeks (treatment $\mathrm{n}=10$ ).

${ }^{y}$ Auxin applied in $50 \%$ ethanol dip.

${ }^{x}$ Concentration applies to each auxin.

"Forty-four percent rooting with water alone.

NS, $* * *$ Nonsignificant or significant at $P=0.05$ or 0.01 , respectively. 
for $8 \mathrm{sec}$ every $8 \mathrm{~min}$ for 3 weeks. The soil was maintained at $\approx 30 \mathrm{C}$ for 3 weeks with heating cables.

In vitro shoot proliferation from cotyledonary nodes. Mature pods obtained from greenhouse-cultivated trees grown from seed were washed with tap water and flamed with $95 \%$ ethanol in a laminar flow hood. Seeds were extracted, and the mucilaginous seed coat was removed. Embryos were germinated on either half-strength MS salts (Murashige and Skoog, 1962) supplemented with $0.3 \mu \mathrm{M}$ thiamine- $\mathrm{HCl}, 2.4 \mu \mathrm{M}$ pyridoxine- $\mathrm{HCl}$, $0.6 \mathrm{~mm} i$-inositol, 4.1 $\mu \mathrm{M}$ nicotinic acid, 26.6 $\mu \mathrm{M}$ glycine, 87.6 mM sucrose, and $8 \mathrm{~g}$ agar/liter; or Woody Plant Medium (WPM) (Lloyd and McCown, 1980), supplemented with $88.8 \mathrm{~mm}$ fructose and $2 \mathrm{~g}$ gellan gum/liter (GelRite). The $\mathrm{pH}$ of both media was adjusted to 5.7 before autoclaving.

Epicotyls were removed 4 to 6 weeks after seeds had germinated. In the first experiment, roots were removed and explants were transferred to fresh WPM as formulated previously and supplemented with 0 or $4.44 \mu \mathrm{M} \mathrm{BA}$ and $0,0.005,0.01$, 0.05 , or $0.1 \mu \mathrm{M}$ TDZ applied before autoclaving. In the second experiment, cotyledonary nodes were cultured with or without roots and with or without cotyledons on WPM with $0.05 \mu \mathrm{M}$ TDZ. Shoots were counted and length measured 4 weeks after treatments were imposed in both experiments.

$\mathrm{CO}_{2}$ chambers. High $\mathrm{CO}_{2}$ treatments were conducted in clear acrylic chambers placed in the culture room and received compressed $\mathrm{CO}_{2}$ and air mixed with a Matheson flowmeter and bubbled through distilled water to increase relative humidity. Final concentration of $\mathrm{CO}_{2}$ in the chamber was maintained at $20,000 \mathrm{ppm}$. The chamber was held at a $29 / 25 \mathrm{C}$ day/night cycle.

Diurnal $\mathrm{CO}_{2}$ changes in vitro. Test tubes $(50 \mathrm{ml}$ headspace) containing $10 \mathrm{ml}$ semi-solid WPM supplemented with $88.8 \mathrm{mM}$ fructose (with or without leafy axillary shoots originated from cotyledonary nodes) were capped with polypropylene closures (Bellco Kaputs, Vineland, N. J.) in which silicone septa had been inserted, and wrapped with flexible plastic (Parafilm). Treatments included 16-h photoperiod of $90 \mu \mathrm{mol} \cdot \mathrm{s}^{-1} \cdot \mathrm{m}^{-2} \mathrm{pho}-$ tosynthetic active radiation (PAR) from cool-white fluorescent lamps and $800 \mathrm{ppm} \mathrm{CO}_{2}$ (ambient in culture room = low $\mathrm{CO}_{2}$ ) or $200 \mu \mathrm{mol} \cdot \mathrm{s}^{-1} \cdot \mathrm{m}^{-2}$ PAR from very high output (VHO) coolwhite fluorescent lamps and 20,000 ppm $\mathrm{CO}_{2}$ (high $\mathrm{CO}_{2}$ ). Gas $(1 \mathrm{ml})$ from inside the tubes was extracted with a syringe every $2 \mathrm{~h}$ for $48 \mathrm{~h}$. Each of the four treatments (with or without explants, high or low $\mathrm{CO}_{2}$ and light) consisted of five tubes sampled sequentially every $2 \mathrm{~h}$. Carbon dioxide concentration was measured using a Carle GC 8700 gas chromatography with a thermal conductivity detector.

Effect of high $\mathrm{CO}_{2}$ and high light levels. Three types of shoots were transferred to tubes with $10 \mathrm{ml}$ semisolid WPM plus 88.8 mM fructose and capped with polypropylene closures (Kaputs): 1) new shoots induced and elongated in vitro under low light and low $\mathrm{CO}_{2}$ from five-node plagiotropic cuttings from greenhouse-grown trees; 2$)$ axillary shoots $(\approx 5 \mathrm{~cm})$ from cotyledonary nodes cultured in vitro; 3 ) one-node plagiotropic shoots from mature greenhouse-grown trees. The new secondary shoots were subculture under either high light $\left(150 \mu \mathrm{mol} \cdot \mathrm{s}^{-1} \cdot \mathrm{m}^{-2}\right.$, and high $\mathrm{CO}_{2}$ levels or low light $\left(45 \mu \mathrm{mol} \cdot \mathrm{s}^{-1} \cdot \mathrm{m}^{-2}\right)$ and low $\mathrm{CO}^{2}$ levels. Axillary shoots or nodal cuttings were placed either under high or low $\mathrm{CO}_{2}$ (as above) and high $\left(200 \mu \mathrm{mol} \cdot \mathrm{s}^{-1} \cdot \mathrm{m}^{-2}\right)$ or low light $\left(45 \mu \mathrm{mol} \cdot \mathrm{s}^{-1} \cdot \mathrm{m}^{-2}\right)$ levels obtained either by cheesecloth shading inside the $\mathrm{CO}_{2}$ chamber or by using nonVHO lamps with a lower lamp : area ratio. All data were obtained 4 weeks after initiating treatment. Leaf area was obtained using a LI-COR (LI-COR, Lincoln, Neb.) leaf-area meter.

\section{Results}

In vivo rooting of axillary cotyledonary shoots. Rooting was obtained from $50 \%$ of epicotyls and $80 \%$ of axillary shoots dipped in a solution of IBA and NAA, 4000 ppm each (Table 1). In a second study, using different auxin concentrations, optimum rooting was obtained from 8000 ppm IBA (Table 2). Rooted shoots were transferred to soil and grew into normal plants.

In vitro shoot proliferation from cotyledonary nodes. In the first experiment, proliferation of axillary nodal shoots was induced by BA or TDZ. Maximum proliferation was achieved with $0.1 \mu \mathrm{M}$ TDZ alone (Table 3). Shoots elongated and produced leaves (data not presented) in the presence of cotyledons at all treatments, although high cytokinin concentrations inhibited shoot elongation.

The second experiment was carried out to determine the effect of cotyledons and roots on axillary shoot proliferation and elongation. There was little effect of treatment on budbreak. The presence of either roots or cotyledons promoted elongation; maximum elongation occurred when both roots and cotyledons were present (Table 4).

Diurnal $\mathrm{CO}_{2}$ changes in vitro. In tubes containing medium without cacao shoots, $\mathrm{CO}_{2}$ concentrations were similar to ambient levels found in our culture room, with no appreciable diurnal difference (Table 5). In tubes with cacao shoots, $\mathrm{CO}_{2}$ was depleted during the day, but returned to ambient levels at night. Carbon dioxide concentration in test tubes in the high $\mathrm{CO}_{2}$ chamber ranged from 15,000 to $17,000 \mathrm{ppm}$. No significant diurnal fluctuations in $\mathrm{CO}_{2}$ levels were detected from tubes in the high $\mathrm{CO}_{2}$ chamber.

Effect of light and $\mathrm{CO}_{2}$ on shoot budbreak and elongation. In a preliminary experiment, secondary shoots were cultured in high $\mathrm{CO}_{2}$ receiving PPFD of $150 \mu \mathrm{mol} \cdot \mathrm{s}^{-1} \cdot \mathrm{m}^{-2}$, or in low $\mathrm{CO}_{2}$ receiving $45 \mu \mathrm{mol} \cdot \mathrm{s}^{-1} \cdot \mathrm{m}^{-2}$ Budbreak per explant in high $\mathrm{CO}_{2} /$

Table 3. Effect of TDZ and BA on in vitro axillary shoot proliferation from the cotyledonary node of cacao seedlings without epicotyl. ${ }^{2}$

\begin{tabular}{cccccc}
\hline \hline BA & \multicolumn{5}{c}{$\mathrm{TDZ}(\mu \mathrm{M})$} \\
\cline { 2 - 5 }$(\mu \mathrm{M})$ & 0 & 0.005 & 0.01 & 0.05 & 0.1 \\
\hline \multicolumn{5}{c}{ No. elongated shoots/node } \\
0.0 & $1.0 \pm 0.3^{y}$ & $1.2 \pm 0.5$ & $1.8 \pm 0.2$ & $2.0 \pm 0.9$ & $6.4 \pm 1.2$ \\
4.4 & $1.6 \pm 0.4$ & $1.6 \pm 0.8$ & $2.2 \pm 0.7$ & $3.0 \pm 0.4$ & $5.0 \pm 1.2$ \\
\multicolumn{5}{c}{ Shoot length $(\mathrm{mm})$} \\
0.0 & $27.8 \pm 2.7$ & $33.5 \pm 6.4$ & $46.6 \pm 7.6$ & $32.5 \pm 7.3$ & $22.0 \pm 2.3$ \\
4.4 & $42.8 \pm 9.4$ & $57.5 \pm 6.1$ & $43.8 \pm 6.5$ & $48.5 \pm 3.4$ & $21.8 \pm 3.8$
\end{tabular}

${ }^{2}$ Data obtained after 4 weeks (treatment $n=5$ ).

${ }^{\mathrm{y}} \pm \mathrm{S}$ E.

Table 4. Effect of roots and cotyledons on budbreak and elongation of cotyledonary nodal shoots of cacao. ${ }^{2}$

\begin{tabular}{lcc}
\hline \hline & \multicolumn{3}{c}{ Cotyledons } \\
\cline { 2 - 3 } Roots & Absent & Present \\
\hline & \multicolumn{3}{c}{ Budbreak/node } \\
Absent & $2.6 \pm 0.2^{y}$ & $3.6 \pm 0.5$ \\
Present & $2.1 \pm 0.2$ & $2.3 \pm 0.4$ \\
& \multicolumn{2}{c}{ Elongation/explant $(\mathrm{mm})$} \\
Absent & $5.2 \pm 0.7$ & $27.8 \pm 8.8$ \\
Present & $19.2 \pm 4.2$ & $77.2 \pm 15.3$ \\
\hline
\end{tabular}

${ }^{2}$ Data obtained after 4 weeks (treatment $n=10$ to 25 ). Cotyledonary nodes were cultured in WPM supplemented with $0.05 \mu \mathrm{M} \mathrm{TDZ}$. ${ }^{ \pm} \pm S E$. 
Table 5. Diurnal $\mathrm{CO}_{7}$ changes in test tubes containing WPM with and without cacao axillary shoots and sealed with Kaput closures and Parafilm.

\begin{tabular}{lcr} 
Cacao & \multicolumn{3}{c}{$\mathrm{CO}_{2}(\mathrm{ppm} \pm \mathrm{SE})^{\mathbf{2}}$} \\
\cline { 2 - 3 } shoot & \multicolumn{1}{c}{ Day } & \multicolumn{1}{c}{ Night } \\
& \multicolumn{3}{c}{$800 \mathrm{ppm} \mathrm{CO}_{2}$} \\
Absent & $883 \pm 62$ & $1,042 \pm 212$ \\
Present & $72 \pm 35$ & $949 \pm 192$ \\
& \multicolumn{2}{c}{$20,000 \mathrm{ppm} \mathrm{CO}_{2}$} \\
Absent & $15,860 \pm 600$ & $14,906 \pm 393$ \\
Present & $15,709 \pm 661$ & $17.080 \pm 837$
\end{tabular}

${ }^{2} \mathrm{CO}_{2}$ readings obtained every $2 \mathrm{~h}$ for $48 \mathrm{~h} ; 16$-h photoperiod.

Table 6. Effect of $\mathrm{CO}_{2}$ and light levels on budbreak, elongation, and leaf development of axillary shoots from cotyledonary nodes of cacao. ${ }^{2}$

$$
\begin{aligned}
& \text { Light } \\
& \left(\mu \mathrm{mol} \cdot \mathrm{s}^{-1} \cdot \mathrm{m}^{-2}\right)
\end{aligned}
$$

45

200

45

200

45

200

45

200

45

200

\begin{tabular}{cc}
\multicolumn{3}{c}{$\mathrm{CO}_{2}(\mathrm{ppm})$} & \\
\hline 800 & 20.000 \\
&
\end{tabular}

$3.9 \pm 0.6^{y}$ $4.0 \pm 1.2$

$2.2 \pm 0.4$

Elongation/explant ( $\mathrm{mm}$ )

$10.2 \pm 2.8 \quad 18.0 \pm 4.2$ $10.0 \pm 2.1 \quad 14.8 \pm 3.0$

\begin{tabular}{ll}
\multicolumn{3}{c}{ Léaf area $\left(\mathrm{cm}^{2}\right)$} & \\
$1.1 \pm 0.3$ & $2.1 \pm 0.4$ \\
$0.6 \pm 0.1$ & $1.8 \pm 0.2$
\end{tabular}

0.7

Leaf area/explant $\left(\mathrm{cm}^{2}\right)$

$\begin{array}{ll}0.7 & 6.1 \\ 1.9 & 6.8\end{array}$

\section{Leaf no./explant}

$0.4 \pm 0.2 \quad 2.9 \pm 0.5$

$2.9 \pm 1.0 \quad 3.9 \pm 0.5$

${ }^{z}$ Shhoots were cultured on semi-solid WPM. Data obtained after 4 weeks (treatment $\mathrm{n}=8$ to 20 ).

\pm S E.

high light conditions was $0.2 \pm 0.2$ SE as compared to $0.8 \pm$ 0.6 for low $\mathrm{CO}_{2} /$ low light levels. Shoot elongation per bud in high $\mathrm{CO}_{2}$ /high light levels was $8.8 \pm 1.1$ compared to $3.2 \pm$ 2.2 for low $\mathrm{CO}_{2}$ /low light levels. The most striking effect of the high $\mathrm{CO}_{2}$ /hiigh light combination, however, was the normal leaf expansion and development, which was not achieved in previous experiments.

To separate the $\mathrm{CO}_{2}$ effect from the light effect, a factorial experiment was conducted with cotyledonary nodal shoots, using two light levels $\left(45 \mu \mathrm{mol} \cdot \mathrm{s}^{-1} \cdot \mathrm{m}^{-2}\right.$ or $\left.200 \mu \mathrm{mol} \cdot \mathrm{m}^{-1} \cdot \mathrm{m}^{-2}\right)$ and two $\mathrm{CO}_{2}$ levels (Table 6). High levels of $\mathrm{CO}_{2}$ significantly decreased budbreak and increased elongation, as in the previous experiment, while light intensity had no effect on budbreak or elongation. Average area per leaf and per explant was greater with high $\mathrm{CO}_{2}$ (Fig. 1). Leaves were smaller under high light, but the number of leaves and total leaf area per explant increased.

The same $\mathrm{CO}_{2}$ and light levels were used with single-node plagiotropic cuttings from mature cacao trees. The high light level increased budbreak in low and high $\mathrm{CO}_{2}$ (Table 7). Shoot elongation and number of leaves per explant were increased by the high light level at either $\mathrm{CO}_{2}$ level. High $\mathrm{CO}_{2}$ increased budbreak and elongation significantly under low light; however, under high light there was no $\mathrm{CO}_{2}$ effect on budbreak and the

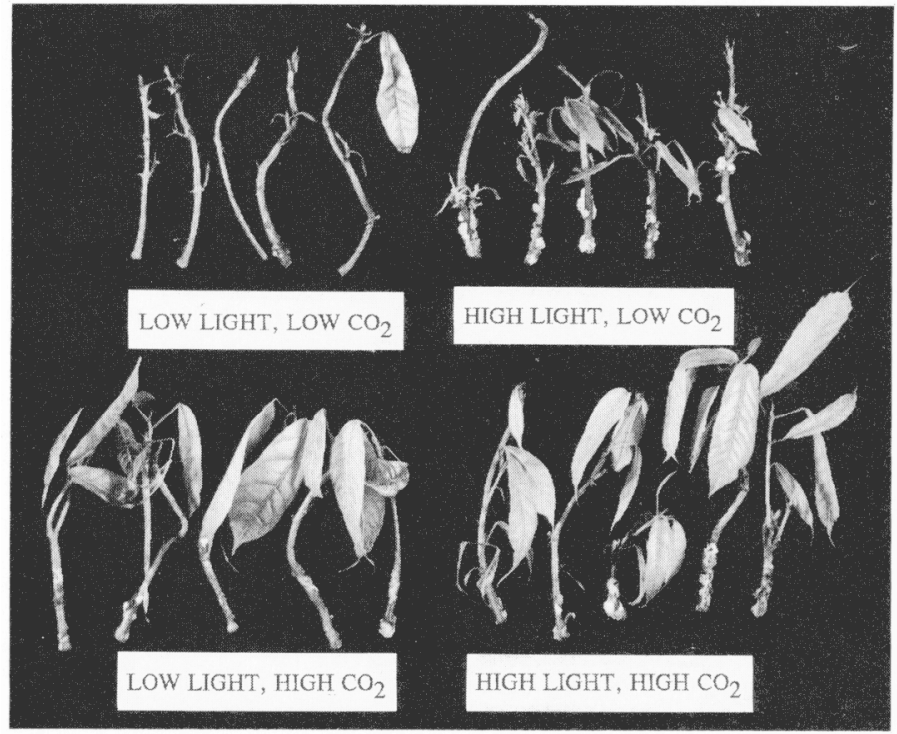

Fig. 1. Response of axillary nodal shoots of cacao to low and high levels of light and $\mathrm{CO}_{2}$ (see Table 6).

Table 7. Effect of $\mathrm{CO}_{2}$ and light levels on budbreak, elongation, and leaf development from nodes derived from mature trees of cacao. ${ }^{z}$

\begin{tabular}{lcc}
\hline \multirow{2}{*}{$\begin{array}{l}\text { Light } \\
\left(\mu \mathrm{mol} \cdot \mathrm{s}^{-1} \cdot \mathrm{m}^{-2}\right)\end{array}$} & \multicolumn{2}{c}{$\mathrm{CO}_{2}(\mathrm{ppm})$} \\
\cline { 2 - 3 } 45 & \multicolumn{2}{c}{ Budbreak/explant } \\
200 & $0.4 \pm 0.1^{\mathrm{y}}$ & $0.7 \pm 0.1$ \\
& $1.0 \pm 0.1^{\mathrm{y}}$ & $1.0 \pm 0.1$ \\
45 & \multicolumn{1}{c}{ Elongation/explant $(\mathrm{mm})$} \\
200 & $1.3 \pm 0.3^{\mathrm{y}}$ & $2.6 \pm 0.4$ \\
& $3.9 \pm 0.5^{\mathrm{y}}$ & $4.4 \pm 0.6$ \\
45 & \multicolumn{2}{c}{ Leaf no./explant } \\
200 & $0.0 \pm 0.0^{\mathrm{y}}$ & $0.1 \pm 0.0$ \\
\hline
\end{tabular}

${ }^{z}$ Shoots were cultured on semi-solid WPM. Data obtained after 4 weeks (treatment $n=30$ to 39 ).

${ }^{y} \pm S E$.

increase in elongation was not significant. The greatest elongation was achieved under high $\mathrm{CO}_{2}$ /ligh light. High $\mathrm{CO}_{2}$ increased the number of leaves produced under high but not under low light.

Subculture of cotyledonary nodal shoots. Axillary cotyledonary shoots from high $\mathrm{CO}_{2}$ were dissected into nodal cuttings and recultured under high $\mathrm{CO} /$ high light. Each axillary shoot averaged 5.6 explants. After 1 month, $80 \%$ of explants produced growing buds, some of which developed leaves, and roots (Fig. 2). Similar results were obtained with shoots from mature trees (Figs. 3 and 4).

\section{Discussion}

The difficulty of getting cacao to grow and proliferate shoots in vitro has been a common observation of many researchers (see introduction). One exception to this generalization has been cotyledonary nodal tissue, but the growth of axillary shoots appeared to be cotyledon-dependent, and subculture cotyledonary axillary shoots failed to grow (Janick and Whipkey, 1985). Our present results indicate that axillary shoots of cacao grow normally in vivo and that roots can partially substitute for cotyledons in promoting elongation of axillary shoots in vitro. 


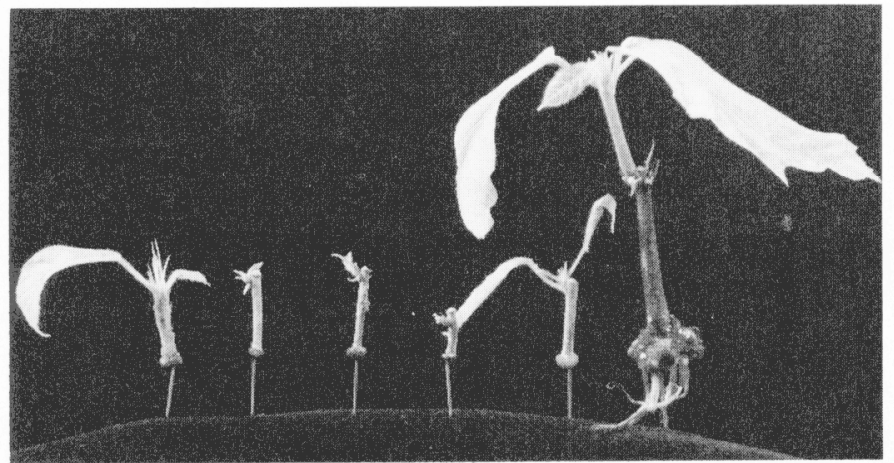

Fig. 2. Growth of subculture axillary shoots under high light and high $\mathrm{CO}_{2}$ levels after 4 weeks. The six cuttings were obtained from a single elongated shoot. Note rooting of the basal microcutting.

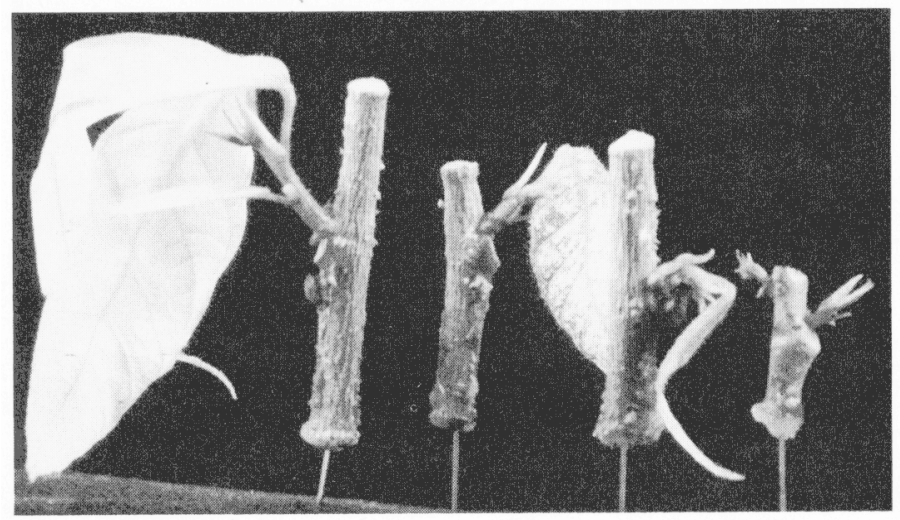

Fig. 3. Büdbreak 'and normal leaf ' development from nodal cuttings of mature plants induced by high $\mathrm{CO}_{2}$ and high light levels.

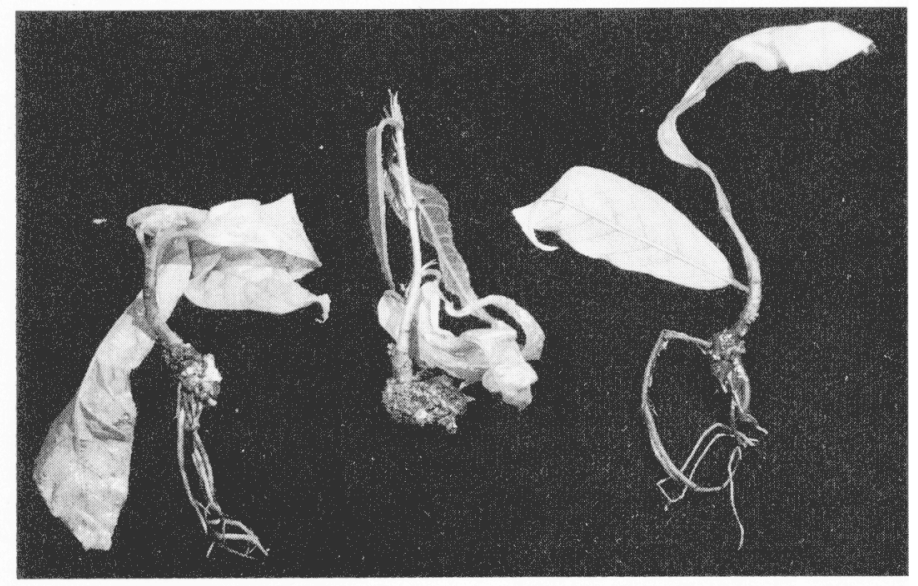

Fig. 4. Growth of subculture secondary shoots from mature plants induced by high $\mathrm{CO}_{2}$ and high light levels.

This substitution suggests that the lack of growth of axillary shoots in vitro is due to nutrition rather than the absence of any cotyledonay promotive factor. It seems unlikely that the promotive factor of roots is cytokinin, because treatment with various kinds, concentrations, and times of application of cytokinins has failed to be promotive (Adu-Ampomah et al., 1988; Bertrand, 1987; Blake and Maxwell, 1984; Dufour and Dublin, 1985; Janick and Whipkey, 1985; Legrand and Mississo, 1986; Litz, 1986; Orchard et al., 1979; Passey and Jones, 1983).

A polysaccharide gum is ubiquitous in all tissues of cacao (Adomako, 1972; Blake and Maxwell, 1984; Blakemore et al.,
1966; Brooks and Guard, 1952; Legrand et al., 1986; Orchard et al., 1979; Passey and Jones, 1983; Whistler et al., 1956). Lack of growth of cacao in tissue culture under conventional systems may be due to interference (either physical or chemical) by this gum (Figueira et al., 1989). The growth of rooted cotyledonary axillary shoots in vivo and the absence of growth in vitro are compatible with the hypothesis that shoots are not being properly nourished either from the medium or from photosynthesis.

Studies of diurnal changes in $\mathrm{CO}_{2}$ within culture vessels containing cacao explants indicate that $\mathrm{CO}_{2}$ is being depleted during the day. The enhancement of shoot elongation and leaf development under a high $\mathrm{CO}_{2} /$ high light regime in this study is consistent with the hypothesis that an increase in photosynthesis by high light levels, high $\mathrm{CO}_{2}$, or both, is responsible for the improved performance of cacao in vitro (Infante et al., 1989; Kozai, 1990; Lakso et al., 1987).

The positive results for in vitro propagation-of cacao axillary buds recently reported by Flynn et al. (1990) are puzzling, because no single factor was implicated as essential. We suggest the main factor in their results is due to a high light level (daily average of $175 \mu \mathrm{mol} \cdot \mathrm{s}^{-1} \cdot \mathrm{m}^{-2}$ ), but we do not rule out some undetected $\mathrm{CO}_{2}$ effect.

In conclusion, our results indicate that high $\mathrm{CO}_{2}$ and high light levels enhanced in vitro shoot elongation and leaf development of cacao shoots and microcuttings. Apparently, improved photosynthesis overcomes the inability of cacao to respond to in vitro conditions. The benefits of high $\mathrm{CO}_{2}$ /high light were observed with axillary shoots from cotyledonary nodes and nodel cuttings from mature trees as well as subcultures from these shoots. Enhanced rooting of axillary and mature shoots has been observed under this regime. This study confirms the beneficial effects of $\mathrm{CO}_{2}$ enrichment reported by Kozai (1990) for various crops, but the $\mathrm{CO}_{2}$ levels we used for cacao are considerably higher $\left(20,000\right.$ ppm vs. 2000 to 3000 ppm). The optimum $\mathrm{CO}_{2}$ levels for cacao remains to be determined. Our results suggest that a system for rapid micropropagation of cacao should be feasible with high light and high $\mathrm{CO}_{2}$ levels.

\section{Literature Cited}

Adomako, D. 1972. Cocoa pod husk pectin. Photochemistry 11:11451148.

Adu-Ampomah, Y., F. Novak, R. Afzar, and M. Van Durren. 1988. - Determination of methodology to obtain shoot tip culture of cocoa. Proc. 10th Intl. Cocoa Res. Conf., Santo Domingo, Dominican Republic, 17-23 May 1987.

Bertrand, B. 1987. Quelques aspects du microbouturage du cacaoyer (Theobroma cacao L.). Café Cacao Thé 31:175-182.

Blake, J. and P. Maxwell. 1984. Tissue culture propagation of cacao by the use of axillary buds. Proc. Intl. Conf. Cocoa and Coconuts, Kuala Lumpur, Malaysia.

Blakemore, W. R., E.T. Dewar, and R.A. Hedge. 1966. Polysaccharides of the cocoa pod husk. J. Sci. Food Agr. 17:558-560.

Brooks, E.R. and A.T. Guard. 1952. Vegetative anatomy of Theobroma cacao. Bet. Gaz. 13:444-454.

Dufour, M. and P. Dublin. 1985. Quelques données sur la multiplication végétative in vitro des cacaoyers cultivés (Theobroma cacao L.). Café Cacao Thé 29:235-244.

Figueira, A., A. Whipkey, and J. Janick. 1989. Gum in Theobroma cacao L.: A potential deterrent for micropropagation. HortScience 24:121. (Abstr.)

Flynn, W. P., L.J. Glicenstein, and P.J. Fritz. 1990. Theobroma cacao L.: An axillary bud in vitro propagation procedure. Plant Cell Organ and Tissue Culture 20:111-117. 
Janick, J. and A. Whipkey. 1985. Axillary proliferation of shoots from cotyledonary nodal tissue of cacao. Rev. Theobroma 15:125-131.

Infante, R., E. Magnanini, and B. Righetti. 1989. The role of light and $\mathrm{CO}_{2}$ in optimizing the conditions for shoot proliferation of $\mathrm{Ac}$ tinidia deliciosa in vitro. Physiol. Plantarum 77:191-195.

Kozai, Y. 1990. Micropropagation under photoautotrophic conditions, p. 449471. In: P. Debergh and R.H. Zimmerman (eds.). Micropropagation: technology and applications. Kluwer Academic, .Dordrecht, The Netherlands.

Lakso, A. N., B.I. Reisch, J. Mortensen, and M.H. Roberts. 1986. Carbon dioxide enrichment for stimulation of growth of in vitropropagated grapevines after transfer from culture. J. Amer. Soc. Hort. Sci. 111:634-638.

Legrand, B. and E. Mississo. 1986., Influence de la taille des explantats et des régulateurs de croissance sur le développement des tissus de Theobroma cacao L., var. Amelonado cultivés in vitro. Café Cacao TM 30:239-246.

Legrand, B., C. Cilas, and E. Mississo. 1984. Comportment des tissus de Theobroma cacao L. var. Amelonado cultivés in vitro. Café Cacao Thé 28:245-250.

Litz, P. 1986. Tissue culture studies with Theobroma cacao, p. 111-120. In: P.S. Dimick (ed.). Proc. Cacao Biotechnol. Symp. Dept. Food Sci., College of Agr. The Pennsylvania State Univ., College Park.

Lloyd, G. and B. McCown. 1980. Commercially-feasible micropropagation of mountain laurel, Kalmia latiflora, by use of shoot-tip culture. Proc. Intl. Plant Prop. Soc. 30:421-427.

Murashige, T. and F. Skoog. 1962. A revised medium for rapid growth and bioassays with tobacco tissue cultures. Physiol. Plantarum 15:473497.

Orchard, J. E., H.A. Collin, and K. Hardwick. 1979. Culture of shoot apices of Theobroma cacao. Physiol. Plantarum 47:207-210.

Passey, A.J. and O.P. Jones. 1983. Shoot proliferation and rooting in vitro of Theobroma cacao L. type Amelonado. J. Hort. Sci. 58:589592.

Whistler, R. L., E. Masak, Jr., and R.A. Plunkett. 1956. Cacao polysaccharides. J. Amer. Chem. Soc. 78:2851-2853. 